\title{
Origin and metamorphism of graphite from Formiga, Minas Gerais (Brazil)
}

\author{
Luiza Carneiro de Rezende ${ }^{* *}(\mathbb{D}$, Alexandre de Oliveira Chaves $\mathbb{1}$, Sérgio Luis Lima de Moraes Ramos²
}

\begin{abstract}
During the Paleoproterozoic Era, the Brazilian cratons experienced orogenic events that modified the archean basement and sedimentary successions. In the southern São Francisco Craton, it can be recognized evidence of an orogenic event that happened between Rhyacian and Orosirian periods. It is related to the closure of an oceanic basin at this time, which led to the collision between the Archean Divinópolis and Campo Belo metamorphic complexes. Graphite schist occurs close to the cities of Formiga and Itapecerica (Minas Gerais), located between these complexes. To contribute to the understanding of the origin and metamorphism of the graphite from Formiga, petrographic studies, $\mathrm{X}$-ray diffraction (XRD) and Raman spectroscopy analyses have been done. XRD and Raman methods revealed that the temperatures recorded by graphite are around $460^{\circ} \mathrm{C}$. However, Raman data showed that the crystallite sizes correspond to higher metamorphic grade conditions (amphibolite to granulite facies). Temperatures of $460^{\circ} \mathrm{C}$ are probably associated with hydrothermal processes along faults in post-collisional stage. The presence of todorokite, a mineral typical of deep-sea Mn nodules formed by microorganisms, in association with graphite from Formiga, suggests a biogenic origin for the graphite occurrence.
\end{abstract}

KEYWORDS: Southern São Francisco Craton; Raman spectroscopy; X-ray diffraction; graphite.

\section{INTRODUCTION}

Graphite and diamond are the polymorph occurrence of native carbon on the nature (Harlow 1998). Graphite has a growing economic value due to its modern technological use as graphene source (Simandl et al. 2015). Formed in several geological settings, graphite is most commonly found in metamorphic rocks, especially in orogenic belts. Graphite can be formed through maturation and metamorphism of biogenic carbonaceous material (CM); as precipitation from C-O-H fluids; mantle-derived; and through reduction of carbonates (Simandl et al. 2015).

There is a vast combination of variables like temperature, pressure, kinetics, composition of country rocks and presence or absence of fluids that can influence the formation of this mineral (Wintsch et al. 1981, Luque et al. 1998, Galvez et al. 2013). The graphite formed by biogenic CM undergoes a progressive and irreversible process called graphitization (Buseck and Beyssac 2014). It occurs in temperature and pressure of burial metamorphism, and decreases the hydrogen-to-carbon $(\mathrm{H} / \mathrm{C})$ and oxygen-to-carbon $(\mathrm{O} / \mathrm{C})$ ratios, transforming disordered and non-crystalline $\mathrm{CM}$ in crystalline graphite (Kwiecińska and Petersen 2004) (Fig. 1). The process of

${ }^{1}$ Universidade Federal de Minas Gerais - Belo Horizonte (MG), Brazil. E-mails: luizacrez@gmail.com, alochaves@yahoo.com.br

${ }^{2}$ Centro de Tecnologia em Nanomateriais e Grafeno, Universidade Federal de Minas Gerais - Belo Horizonte (MG), Brazil. E-mail: slramos@ctnano.org

${ }^{*}$ Corresponding author. graphitization does not depend on the metamorphic pressure, although it is influenced by the oxygen fugacity and metamorphic temperature (Tagiri and Oba 1986). There are two forms to quantify the metamorphic temperature associated to the graphitization of biogenic CM:

- by Raman spectroscopy geothermometry, from low $\left(\sim 330^{\circ} \mathrm{C}\right)$ to high-grade metamorphism $\left(\sim 600^{\circ} \mathrm{C}\right)$ (Beyssac et al. 2002);

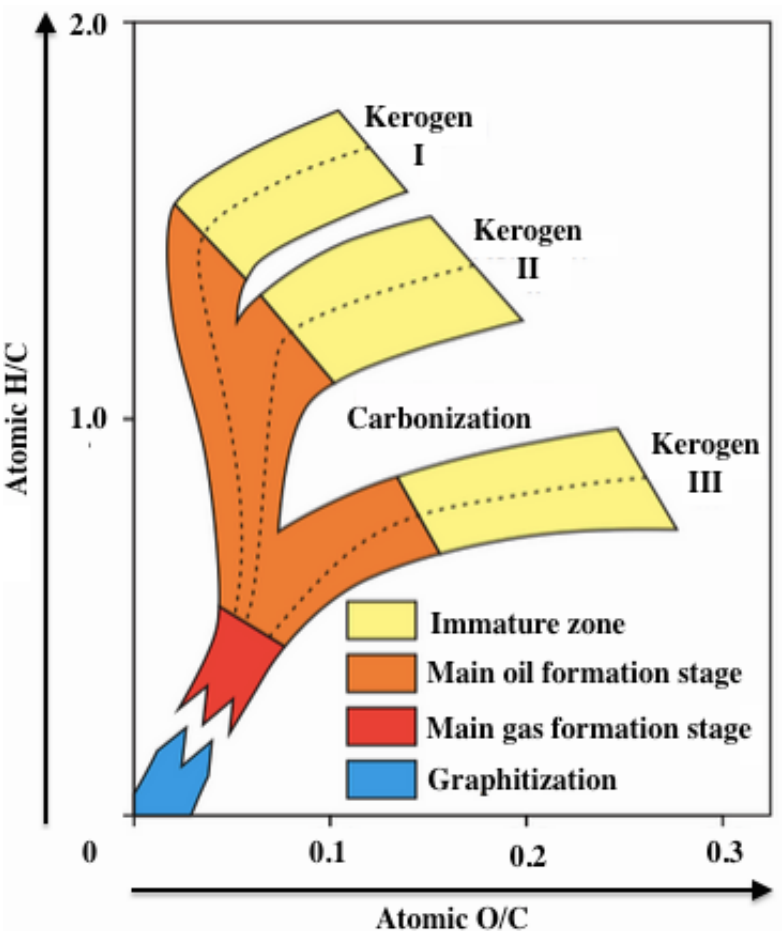

Source: modified from Buseck and Beyssac (2014).

Figure 1. Kerogen maturation in terms of $\mathrm{H} / \mathrm{C}$ and $\mathrm{O} / \mathrm{C}$ atomic ratios. 
- by X-ray diffraction (XRD) geothermometry, for metamorphism above $600^{\circ} \mathrm{C}$ (Wada et al. 1994).

An efficient method to analyse the origin of CM is to evaluate its isotopic composition, inasmuch as Buseck and Beyssac (2014) indicate that this kind of deposit preserves the $\delta^{13} \mathrm{C}$ between -35 and -20\% biologic signature. A variety of minerals can be formed in this condition, as is the case of todorokite ( $\left.(\mathrm{Mn}, \mathrm{Mg}, \mathrm{Ca}, \mathrm{Ba}, \mathrm{Na}, \mathrm{K})_{2} \mathrm{Mn}_{5} \mathrm{O}_{12} \cdot 3 \mathrm{H}_{2} \mathrm{O}\right)$, which is formed by the accumulation of Mn-oxides (Lowenstam 1981), and can be used as evidence of biogenic activity on seafloor (Burns et al. 1983).

Graphite schist occurs at southern São Francisco Craton, in the Itapecerica Supracrustal Sequence, associated with the collision between the Archean Divinópolis and Campo Belo metamorphic complexes. In Itapecerica (Minas Gerais (MG), Brazil), Miranda et al. (2019) characterized two different forms of graphite. They presented $\delta^{13} \mathrm{C}$ between -21.23 and -27.89\%o, indicating biogenic source, and high-grade metamorphism associated with a syn-collisional stage, with average temperature around $729^{\circ} \mathrm{C}$ (metamorphic graphite), and hydrothermalism associated with post-collisional stage, around $611^{\circ} \mathrm{C}$ (recrystallized graphite).
In order to complement the study of Miranda et al. (2019), this paper aims to characterize the origin, crystallinity and metamorphism temperature of graphite from an area near the city of Formiga (MG), a city located about $40 \mathrm{~km}$ west of Itapecerica (MG) (Fig. 2), using XRD and Raman spectroscopy. The results are compared to previous studies to corroborate to the understanding of the tectonic model proposed for the Rhyacian-Orosirian orogeny in the southern São Francisco Craton.

\section{GEOLOGICAL SETTING}

The São Francisco Craton (SFC) is a tectonic domain (Almeida 1977) (Fig. 2) surrounded by Neoproterozoic orogens. Its southern sector is composed by Archean crust, with age between 3.5 and $2.6 \mathrm{Ga}$, that is formed mostly by granite-gneisses rocks (Farina et al. 2015) and greenstone belts (Rio das Velhas Supergroup) constituted by mafic-ultramafic, intermediate-felsic volcanic and volcanoclastic rocks (Noce et al. 1998) with terrigenous sediments (Dorr 1969, Baltazar and Zucchetti 2007).

The basement comprises the Campo Belo, Divinópolis, Bonfim and Belo Horizonte metamorphic complexes (Fig. 2)

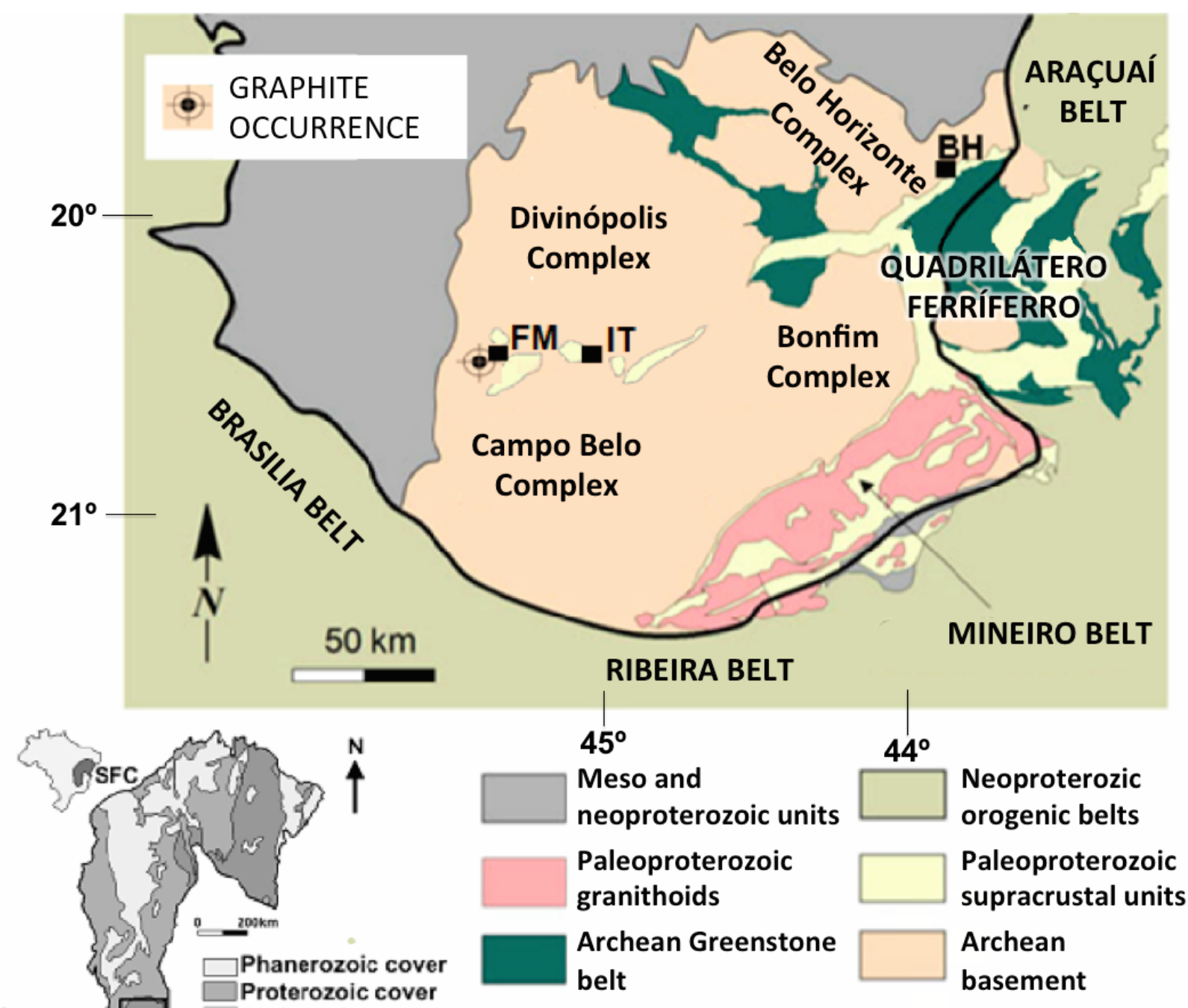

BH: Belo Horizonte; FM: Formiga; IT: Itapecerica.

Source: modified from Alkmim and Teixeira (2017).

Figure 2. Geology of meridional sector of São Francisco Craton. 
(Machado Filho et al. 1983, Teixeira et al. 1996). The supracrustal sequence is formed by the Minas Supergroup, which is characterized by clastic-chemical metasedimentary rocks from the Paleoproterozoic (minimum deposition around 2.0 $\mathrm{Ga}$ ), including the banded iron formations of the Quadrilátero Ferrífero (Machado et al. 1996, Moreira et al. 2016), and also the Bambuí Group, formed by pelitic-carbonate sedimentary rocks with Neoproterozoic age (Alkmim and MartinsNeto, 2001).

The Mineiro Belt (Noce et al. 1998, Ávila et al. 2014, Teixeira et al.2015) was formed by accretionary orogeny and occurred between Rhyacian and Orosirian, which resulted in extensive reworking of regions placed at the margins of the southern SFC (Noce et al. 2007). Chaves et al. (2015) suggested the existence of a Paleoproterozoic event in the Itapecerica region based on chemical ages found in monazites in sillimanite-cordierite-garnet-biotite gneiss (graphite-rich khondalitic rocks), which was confirmed by Carvalho et al. (2017), that found isotopic ages from zircons of $2.05-2.03 \mathrm{Ga}(\mathrm{U}-\mathrm{Pb})$ in the interior of the basement.

Occurrences of graphite with $\delta^{13} \mathrm{C}$ between -21.23 and $-27.89 \%$, indicating biogenic origin, (Miranda et al. 2019) are reported in this area, where Itapecerica Supracrustal Sequence has been described (Campello et al. 2015, Chaves et al.2015, Teixeira et al. 2017). The studied area is located near the city of Formiga, where the graphite schist occurs between the Divinópolis and Campo Belo complexes (Fig. 2).

\section{METHODS AND RESULTS}

Three samples were collected at the Formiga area (20²6'40.4”S, 40³0'04.3”W). Samples LR44A and LR44C were chipped from an abandoned trench (Fig. 3A) and sample LR44B was chipped about $5 \mathrm{~m}$ away. Both collection spots are formed by fine grained graphite schist composed of quartz, graphite and mica, with presence of vertical foliation. In the trench it is possible to notice the presence of quartz veins oblique to the foliation that contain manganese minerals and occur filling fractures. The host rock presents some recrystallization in the contact with the veins. Samples LR44A and LR44B (Fig. 3B) are graphite schist with vertical foliation, while sample LR44C (Fig. 3C) was taken from an associated quartz vein (Fig. 3D), with manganese minerals, oriented N40E/75NW. The visual proportion between graphite and manganese mineral in this sample is $4: 1$. Each sample was between 10 and $20 \mathrm{~cm}$ long and weighed approximately $0.5 \mathrm{~kg}$.

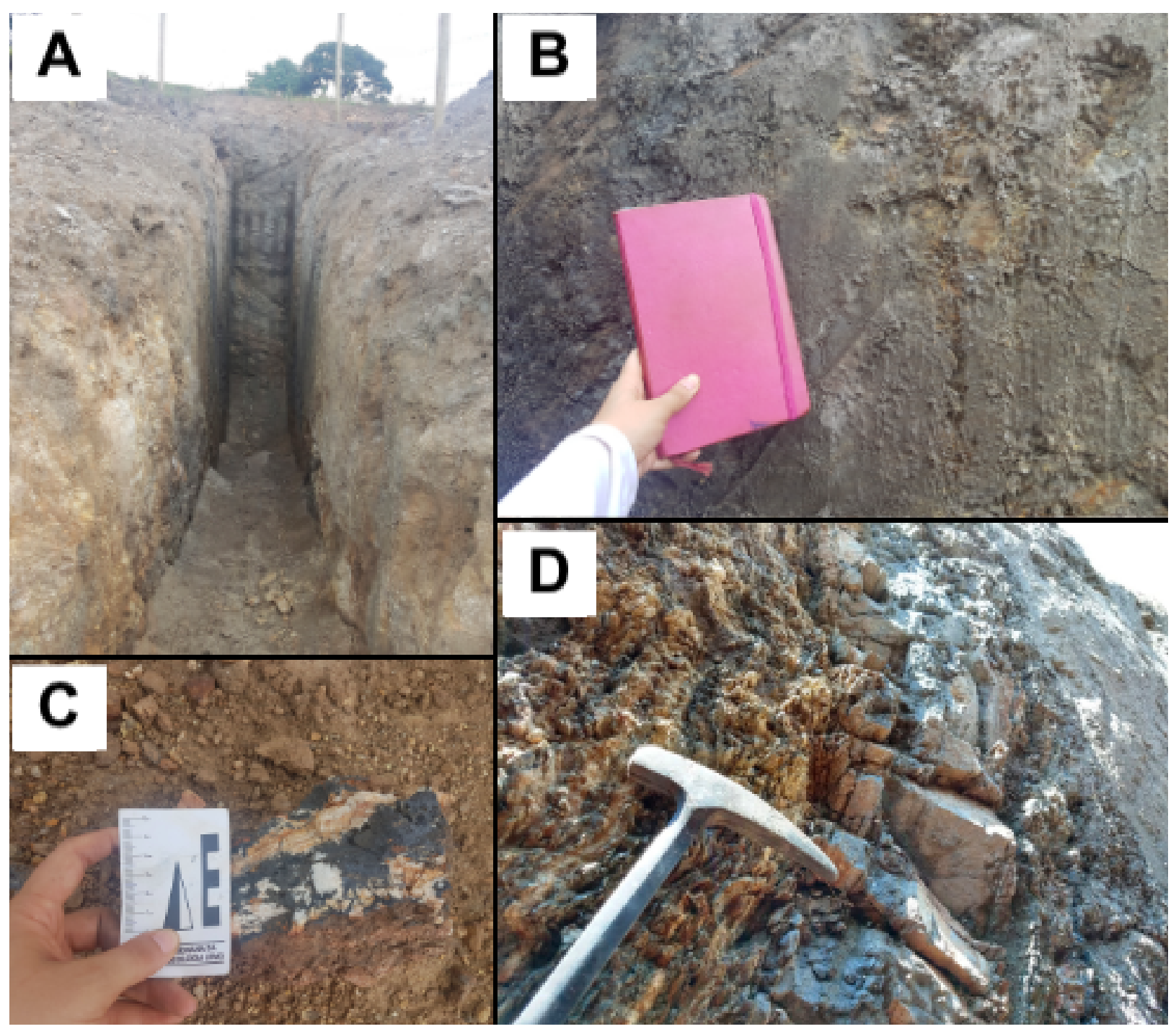

Figure 3. Graphite schist sampling site. (A) Front view of trench; (B) place where samples LR44A and LR44B were collected; (C) sample LR44C, collected from quartz vein with presence of todorokite and manganite; (D) quartz vein where sample LR44C was collected. 


\section{Petrography}

Thin sections of the collected samples were prepared and examined under transmitted and reflected light microscopy at the Centro de Pesquisa (Research Centre) Professor Manoel Teixeira da Costa of Intitute of Geosciences of the Universidade Federal de Minas Gerais (CPMTC-IGC-UFMG), at Belo Horizonte, MG, Brazil.

The studied rocks are fine grained and have granolepidoblastic texture (Fig. 4). They are composed of quartz (50\%), graphite (35\%) and phengite (15\%). Quartz is the dominant mineral in the composition and occurs in anhedral fractured grains. The second main component is graphite, presented in aggregates (LR44A) and in layers parallel with foliation (LR44B). Phengite marks the foliation in both samples, but occurs in larger crystals in sample LR44B than in sample LR44A. The foliation is more evident in sample LR44B than it is in sample LR44A.

\section{X-ray diffraction}

The XRD analyses of graphite were performed in the X-ray Laboratory at CPMTC-IGC-UFMG. The mineral was previously isolated from other minerals of the graphite schist by brushing the graphite-rich portion of the rock, followed by graphite flotation in aqueous environment and drying of the floated grains. PANalytical XPert PRO diffraction instrument with theta-theta geometry was used to record the XRD data, using a $\mathrm{Cu} \mathrm{K} \alpha \mathrm{X}$-ray source ( $40 \mathrm{kV}$ and $45 \mathrm{~mA}$ ). The step size and scan step settings were $0.02^{\circ}, 2 \theta$ and $0.5 \mathrm{~s}$. The high accuracy of the lattice parameter was guaranteed using Rietveld methods (Young 1993) to fit the diffraction data, with starting parameters close to realistic values and equally applied to both samples LR44A and LR44B. Figure 5 shows the XRD results of sample LR44C, composed of todorokite and manganite instead of graphite. The XRD data from the graphite schist samples are organized in Table 1 and their respective diffractogram are presented in Figure 6.

To estimate the crystal size along stacking direction $\left(\mathrm{L}_{\mathrm{c}(002)}\right)$, we used the Equation 1 provided by Baiju et al. (2005).

$$
\mathrm{L}_{\mathrm{c}(002)}=\mathrm{k} \lambda / \beta_{(002)} \cos \theta
$$

In this equation, $\mathrm{k}$ means the shape constant (0.9), $\lambda$ is the $X$-ray wavelength in angstroms (1.5406), $\beta_{(002)}$ represents the full width at half maximum of the peak in radian and $\theta$ correspond to the angle of diffraction in radians. The graphitization degree (GD) has been calculated using the Equation 2 from Tagiri (1981), were $d_{(002)}$ is the interplanar spacing:

$$
\mathrm{GD}=\left\{\left[\mathrm{d}_{(002)}-3.7\right] /\left[\log \left(\mathrm{L}_{\mathrm{c}(002)} / 1,000\right)\right]\right\} \times 100
$$

Moreover, the Equation 3 from Wada et al. (1994) has been used to calculate the metamorphism temperature:

$$
\mathrm{T}\left({ }^{\circ} \mathrm{C}\right)=3.2 \times \mathrm{GD}+280
$$

The average temperature found for samples LR44A and LR44B were $442^{\circ} \mathrm{C}$ and $449^{\circ} \mathrm{C}$ respectively.

The graphs in Figure 7 show correlations that could be done with the results obtained from the XRD data. Figure 7A presents the relationship between interplanar spacing $\left(\mathrm{d}_{(002)}\right)$ and crystallite size $\left(\mathrm{L}_{c(002)}\right)$, that, in accordance with Tagiri and Oba (1986), can give information about the GD. Both samples LR44A and LR44B were classified as graphite as opposed to fully ordered graphite. The two samples presented similar XRD temperatures and are randomly arranged in the line that correlated GD with metamorphic temperature in the Figure 7B.

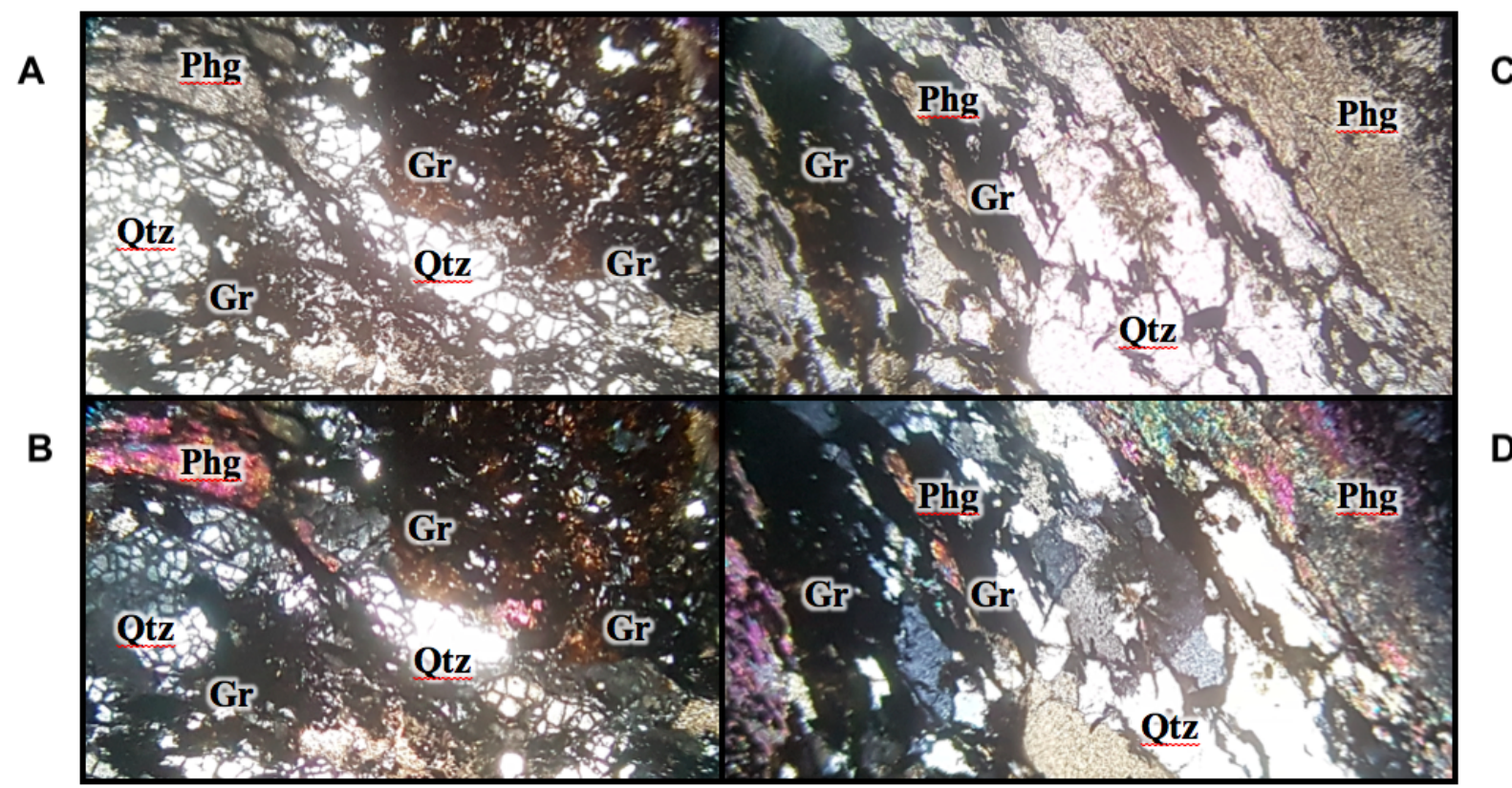

Figure 4. Protomicrographies of samples (A, B) LR44A and (C, D) LR44B on (A, C) plane polarized light and (B, D) crossed polarized light. Samples present granolepidoblastic texture. Graphite occurs in aggregates in sample LR44A, while in sample LR44B it occurs in layers parallel to foliation (marked by phengite). Mineral abbreviations, in accordance to Whitney and Evans (2010), are: Gr: graphite; Qtz: quartz; Phg: phengite. 


\section{Raman spectroscopy}

The Raman spectroscopy analyses were performed in the Technological Center of Nanomaterials (CTnano) at Technological Park of Belo Horizonte - BHTec. The equipment used was a confocal microspore Alpha 300R WITec (Wissenschaftliche Instrumente und Technologie $\mathrm{GmbH}^{\circledR}$, Ulm, Germany) equipped with Nd-YAG laser with double frequency $(2.49 \mathrm{~mW}, \lambda=532.2 \mathrm{~nm})$. The same methodology as applied by Rantitsch et al. (2016) has been used, in which the spectra were obtained with $50 \times$ lens objective. Five scans in the $1,000-3,200 \mathrm{~cm}^{-1}$ spectra (first order $=1,000-2,000 \mathrm{~cm}^{-1}$; second order $=2,200-3,200 \mathrm{~cm}^{-1}$ ) were performed with an acquisition time of $30 \mathrm{~s}$. The analyses were made using the powder extracted from both samples LR44A and LR44B.
In each sample, five fields were randomly selected (Fig. 8A, represented by squares), in which three to five analyses were done per square field (Fig. 8B, represented by crosses). The results of Raman spectroscopy are presented in Table 2 , and the respective spectrum are presented in Figure 9 (sample 44A) and Figure 10 (sample 44B).

The temperature has been calculated by using the Interactive Fitting of Raman Spectra (IFORS) method, provided by Lünsdorf and Lünsdorf (2016). The average temperatures found for each sample were $486^{\circ} \mathrm{C}$ for sample LR44A and $463^{\circ} \mathrm{C}$ for sample LR44B. The graphs from Figure 11 classifies, according to Rantitsch et al. (2016), the metamorphic facies based on interplanar spacing and width at half maximum of the G-band (G HWHM) or area

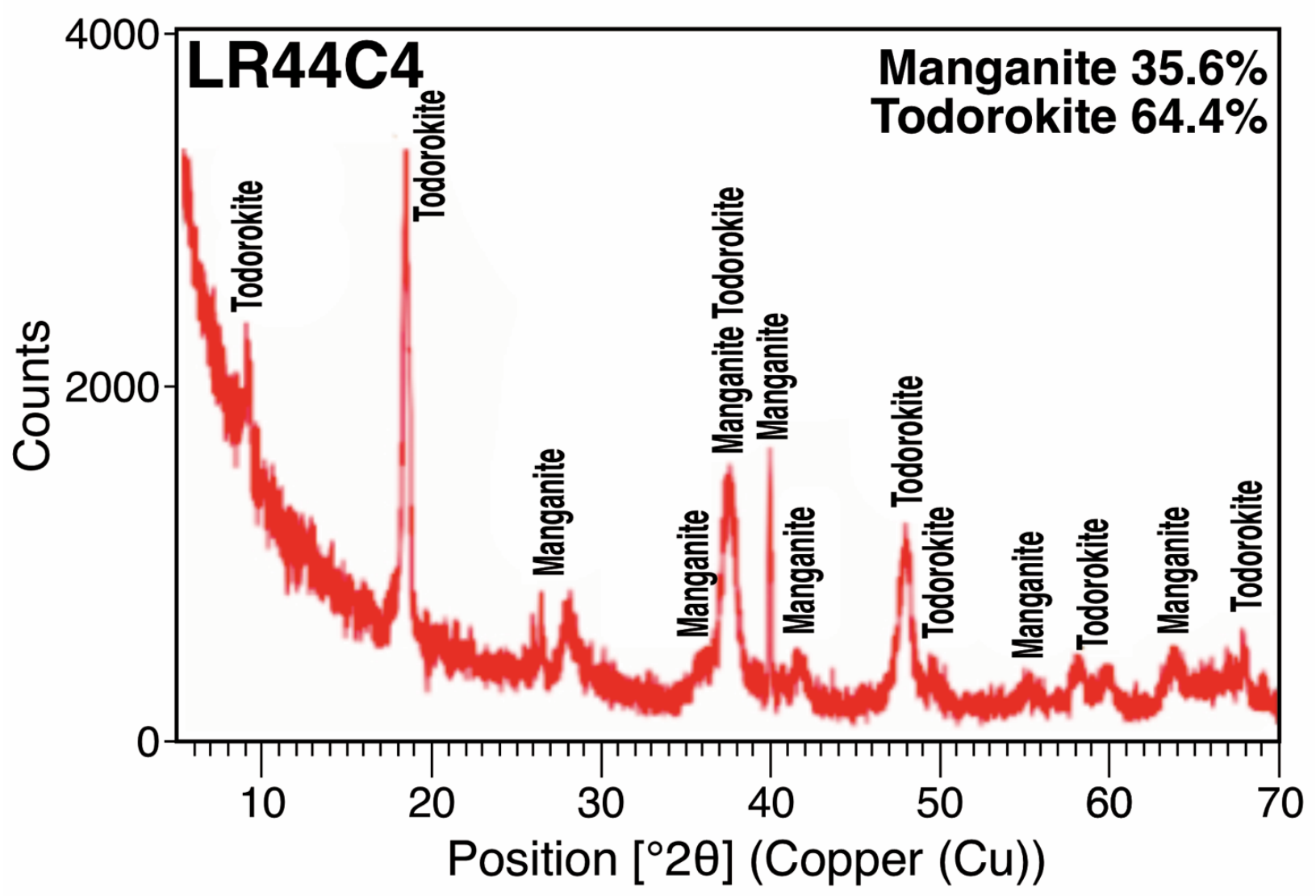

Figure 5. Diffractogram of sample LR44C showing the presence of the biogenic Mn-rich minerals.

Table 1. X-ray diffraction data from LR44A and LR44B, graphite schist samples, in which $\mathrm{d}(002)$ represents interplanar spacing, FWHM is the full width at half maximum of the G-band, $\mathrm{Lc}(002)$ is the crystal size along stacking direction, GD is the graphitization degree and Tis the metamorphic temperature.

\begin{tabular}{|c|c|c|c|c|c|c|c|c|c|}
\hline \multicolumn{10}{|c|}{$\mathrm{X}$-ray diffraction data } \\
\hline Sample & $2 \theta$ & $\mathbf{d}(002)(\AA)$ & $\operatorname{sd} \pm$ & FWHM $(2 \theta)$ & $\operatorname{Lc}(002)(\AA)$ & $\mathbf{s d} \pm$ & GD & $\mathbf{T}\left({ }^{\circ} \mathbf{C}\right)$ & sd \pm \\
\hline LR44A1 & 26.533 & 3.357 & 0.005 & 0.347 & 236 & 25 & 55 & 455 & 23 \\
\hline LR44A2 & 26.411 & 3.372 & 0.01 & 0.402 & 203 & 21 & 47 & 432 & 22 \\
\hline LR44A3 & 26.666 & 3.340 & 0.005 & 0.441 & 185 & 19 & 49 & 437 & 22 \\
\hline LR44A4 & 26.446 & 3.368 & 0.01 & 0.366 & 223 & 23 & 51 & 443 & 22 \\
\hline LR44B1 & 26.556 & 3.354 & 0.005 & 0.330 & 247 & 26 & 57 & 462 & 23 \\
\hline LR44B2 & 26.494 & 3.362 & 0.01 & 0.392 & 208 & 22 & 50 & 439 & 22 \\
\hline LR44B3 & 26.578 & 3.351 & 0.005 & 0.467 & 175 & 18 & 46 & 427 & 21 \\
\hline LR44B4 & 26.413 & 3.374 & 0.01 & 0.297 & 275 & 29 & 58 & 466 & 23 \\
\hline
\end{tabular}

sd: standard deviation. 
ratio (R2). The area ratio is calculated as described as Beyssac et al. (2002) using the first-order peaks at $\sim 1,350 \mathrm{~cm}^{-1}$ (D1 band), $\sim 1,580 \mathrm{~cm}^{-1}$ (G band), and $\sim 1,610 \mathrm{~cm}^{-1}$ (D2 band), by the Equation 4 :

$$
\mathrm{R} 2=\mathrm{D} 1 /(\mathrm{G}+\mathrm{D} 1+\mathrm{D} 2)
$$

The results, showed in Figure 11, revealed that both samples present graphite. In Figure 11A both samples are plotted in upper amphibolite facies, while in Figure 11B they are classified as granulite. The reason why this divergence occurs is explored in the discussion section.

\section{DISCUSSION}

To characterize the graphite schist from Formiga, we correlate X-ray diffraction and Raman spectroscopy from samples LR44A and LR44B. The Table 3 compares metamorphic temperatures acquired from both methods that yielded temperatures around $460^{\circ} \mathrm{C}$. According to Lünsdorf (2015), Raman analyses are reliable for temperatures between 330 and $600^{\circ} \mathrm{C}$, so Raman data presented here are reliable. This temperature disagrees with the high metamorphic degree expected for the area (Chaves et al. 2015). However, it agrees with the results found by Miranda et al. (2019) for hydrothermal recrystallized graphite.
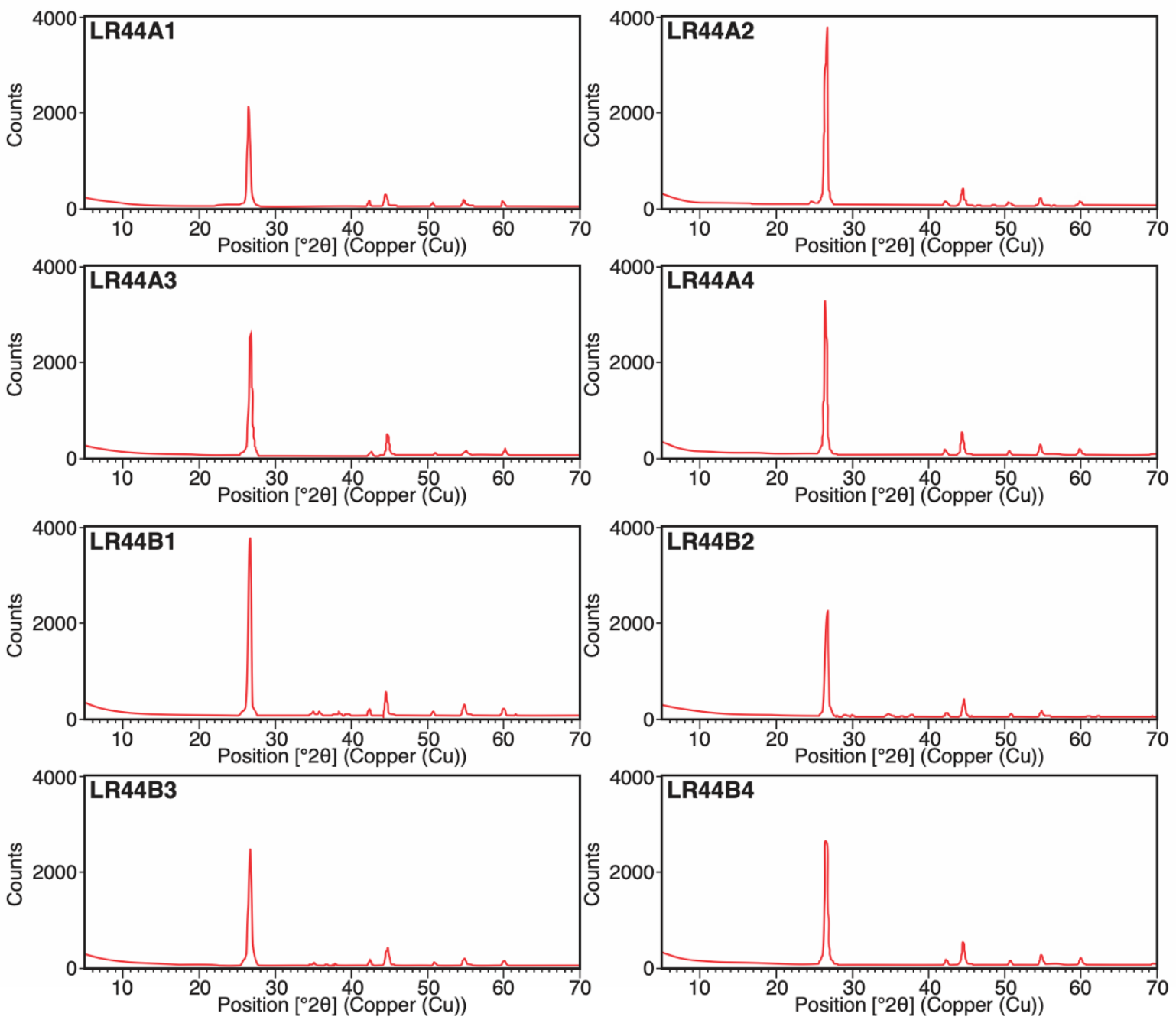

Figure 6. Diffractograms of samples 44A and 44B showing graphite patterns. All peaks are from graphite.
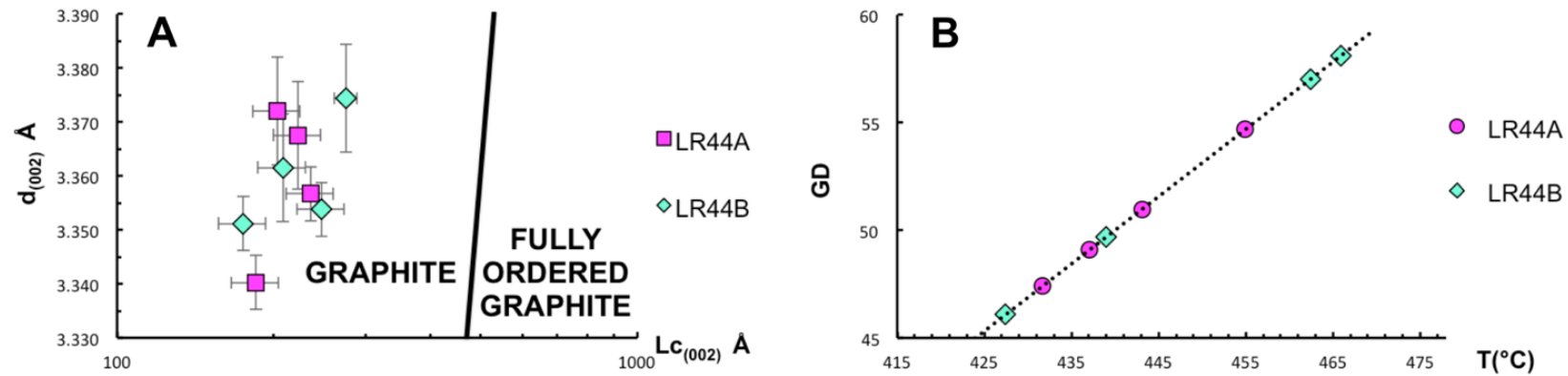

Figure 7. (A) Interplanar spacing $(\mathrm{d}(002))$ versus crystallite size $(\mathrm{Lc}(002))$ (Tagiri and Oba 1986). All samples are classified as graphite, but they aren't fully ordered; (B) Graphitization degree versus X-ray diffraction data temperature (Wada et al. 1994). Samples presented similar $\mathrm{X}$-ray diffraction temperature and are randomly arranged in the trendline. 


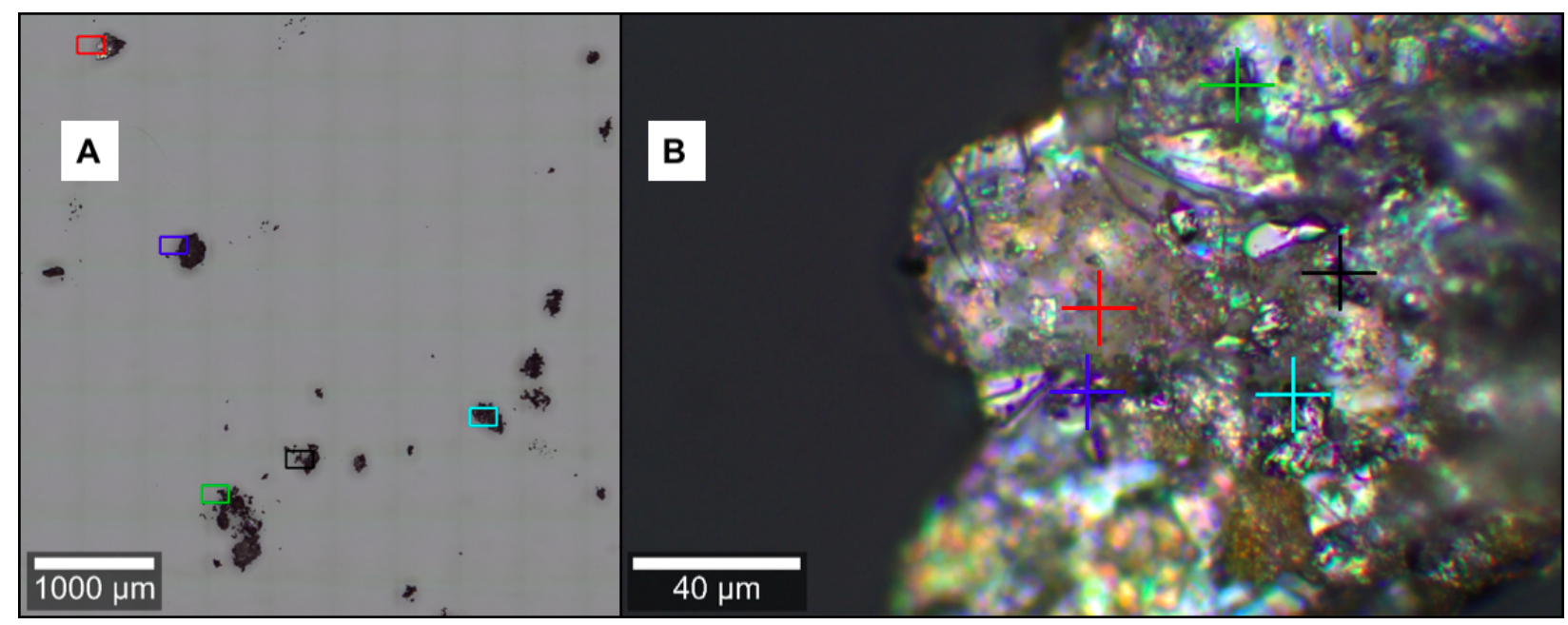

Figure 8. Photomicrographs of graphite powder (extracted from sample LR44A) taken in plane polarized light. (A) Selected fields for analyses represented with squares; (B) a random powder chosen for Raman analyses, in which each cross represents a spot of analyse.

Table 2. Raman spectroscopy data with values obtained by the IFORS method (Lünsdorf and Lünsdorf 2016) from graphite schist samples LR44A and LR44B. G HWHM represents the width at half maximum of the G-band in $\mathrm{cm}-1, \mathrm{R} 2$ is the area ratio and $\mathrm{T}$ is the metamorphic temperature in ${ }^{\circ} \mathrm{C}$.

\begin{tabular}{|c|c|c|c|c|c|c|c|c|}
\hline \multicolumn{9}{|c|}{ Raman spectroscopy data } \\
\hline Sample & G HWHM & $\mathbf{s d} \pm$ & Center & $\mathbf{s d} \pm$ & $\mathbf{R 2}$ & $\mathbf{s d} \pm$ & $\mathbf{T}^{\circ} \mathbf{C}$ & $\operatorname{sd} \pm$ \\
\hline LR44Aalp1 & 7.94 & 0.42 & $1,581.58$ & 0.00 & 0.000 & 0.000 & 521 & 64 \\
\hline LR44Aa1p2 & 7.87 & 0.00 & $1,581.58$ & 0.00 & 0.067 & 0.000 & 496 & 63 \\
\hline LR44Aa1p3 & 7.78 & 0.00 & $1,581.58$ & 0.00 & 0.070 & 0.001 & 410 & 61 \\
\hline LR44Aa1p4 & 8.33 & 0.00 & $1,581.58$ & 0.00 & 0.120 & 0.000 & 492 & 63 \\
\hline LR44Aalp5 & 8.91 & 0.00 & $1,581.58$ & 0.00 & 0.066 & 0.001 & 465 & 62 \\
\hline LR44Aa2p3 & 8.06 & 0.48 & $1,581.58$ & 0.00 & 0.000 & 0.000 & 488 & 63 \\
\hline LR44Aa3p1 & 7.90 & 0.00 & $1,581.58$ & 0.00 & 0.047 & 0.001 & 499 & 63 \\
\hline LR44Aa3p2 & 8.08 & 0.00 & $1,584.06$ & 0.00 & 0.140 & 0.161 & 497 & 63 \\
\hline LR44Aa3p3 & 7.67 & 0.00 & $1,581.58$ & 0.00 & 0.000 & 0.000 & 494 & 63 \\
\hline LR44Aa4p1 & 7.71 & 0.00 & $1,581.58$ & 0.00 & 0.000 & 0.000 & 476 & 63 \\
\hline LR44Aa4p3 & 7.78 & 0.00 & $1,579.09$ & 0.00 & 0.127 & 0.000 & 479 & 63 \\
\hline LR44Aa5p1 & 7.79 & 0.01 & $1,581.58$ & 0.00 & 0.119 & 0.000 & 501 & 63 \\
\hline LR44Aa5p2 & 7.85 & 0.00 & $1,581.58$ & 0.00 & 0.057 & 0.000 & 499 & 63 \\
\hline LR44Aa5p3 & 8.00 & 0.00 & $1,574.12$ & 0.00 & 0.118 & 0.001 & 487 & 63 \\
\hline LR44Ba1p1 & 8.89 & 0.00 & $1,581.58$ & 0.00 & 0.000 & 0.000 & 502 & 63 \\
\hline LR44Ba1p2 & 8.90 & 0.00 & $1,583.28$ & 0.00 & 0.216 & 0.000 & 492 & 63 \\
\hline LR44Ba 1p3 & 8.78 & 0.00 & $1,580.79$ & 0.00 & 0.050 & 0.000 & 498 & 63 \\
\hline LR44Balp4 & 9.58 & 0.01 & $1,582.45$ & 1.44 & 0.044 & 0.001 & 491 & 63 \\
\hline LR44Ba2p1 & 8.12 & 0.00 & $1,580.79$ & 0.00 & 0.056 & 0.000 & 502 & 63 \\
\hline LR44Ba2p2 & 8.17 & 0.01 & $1,575.81$ & 0.00 & 0.060 & 0.000 & 493 & 63 \\
\hline LR44Ba2p3 & 8.46 & 0.00 & $1,583.28$ & 0.00 & 0.035 & 0.000 & 505 & 64 \\
\hline LR44Ba2p4 & 8.94 & 0.02 & $1,578.30$ & 0.00 & 0.081 & 0.000 & 481 & 63 \\
\hline LR44Ba3p3 & 8.01 & 0.00 & $1,580.79$ & 0.00 & 0.000 & 0.000 & 500 & 63 \\
\hline LR44Ba4p1 & 9.09 & 0.01 & $1,583.28$ & 0.00 & 0.144 & 0.002 & 496 & 63 \\
\hline LR44Ba4p2 & 9.82 & 0.00 & $1,583.28$ & 0.00 & 0.063 & 0.000 & 492 & 63 \\
\hline LR44Ba4p3 & 8.51 & 0.00 & $1,588.78$ & 0.00 & 0.088 & 0.000 & 499 & 63 \\
\hline LR44Ba5p1 & 8.36 & 0.00 & $1,588.78$ & 0.00 & 0.039 & 0.000 & 491 & 63 \\
\hline LR44Ba5p2 & 9.32 & 0.00 & $1,588.78$ & 0.00 & 0.052 & 0.000 & 491 & 63 \\
\hline
\end{tabular}

sd: standard deviation. 
The XRD data (Tab. 1) was plotted in graphs to analyze the GD accordantly to its crystallinity. Figure 7A correlates interplanar spacing $\left(\mathrm{d}_{(002)} \mathrm{A}\right)$ and crystallite size $\left(\mathrm{L}_{\mathrm{c}(002)} \mathrm{A}\right)$, and, as suggested by Tagiri and Oba (1986), shows that both samples are classified as graphite between the fields of disordered graphite and fully ordered graphite. This corresponds to the temperatures which were found in this work, as graphite becomes fully ordered around $600^{\circ} \mathrm{C}$ (Beyssac et al. 2002, Lünsdorf 2015). The GD and XRD data temperature (T) are plotted using the equation for graphitization in pelitic rocks (Wada et al. 1994), and data from samples LR44A and LR44B behave similarly, leading to the conclusion that they both have been metamorphized under the same conditions.
The data acquired by Raman spectroscopy (Tab. 2) gave quite controversial results when plotted in graphs that classify the metamorphic facies as proposed by Rantitsch et al. (2016). Figure 11A correlates the interplanar spacing $d_{(002)}$ and half width at half maximum of the G-band (G HWHM) and classifies the sample LR44B as related to the amphibolite facies while the sample LR44A to the upper amphibolite facies. Figure 11B shows the correlation between $d_{(002)}$ and area ratio (R2 from Beyssac et al. 2002) in which both samples are classified as related to the granulite facies. This result was expected assuming the metamorphism considered for the area (Chaves et al. 2015), but it disagrees with the temperatures found by both methods. Also, the samples are classified

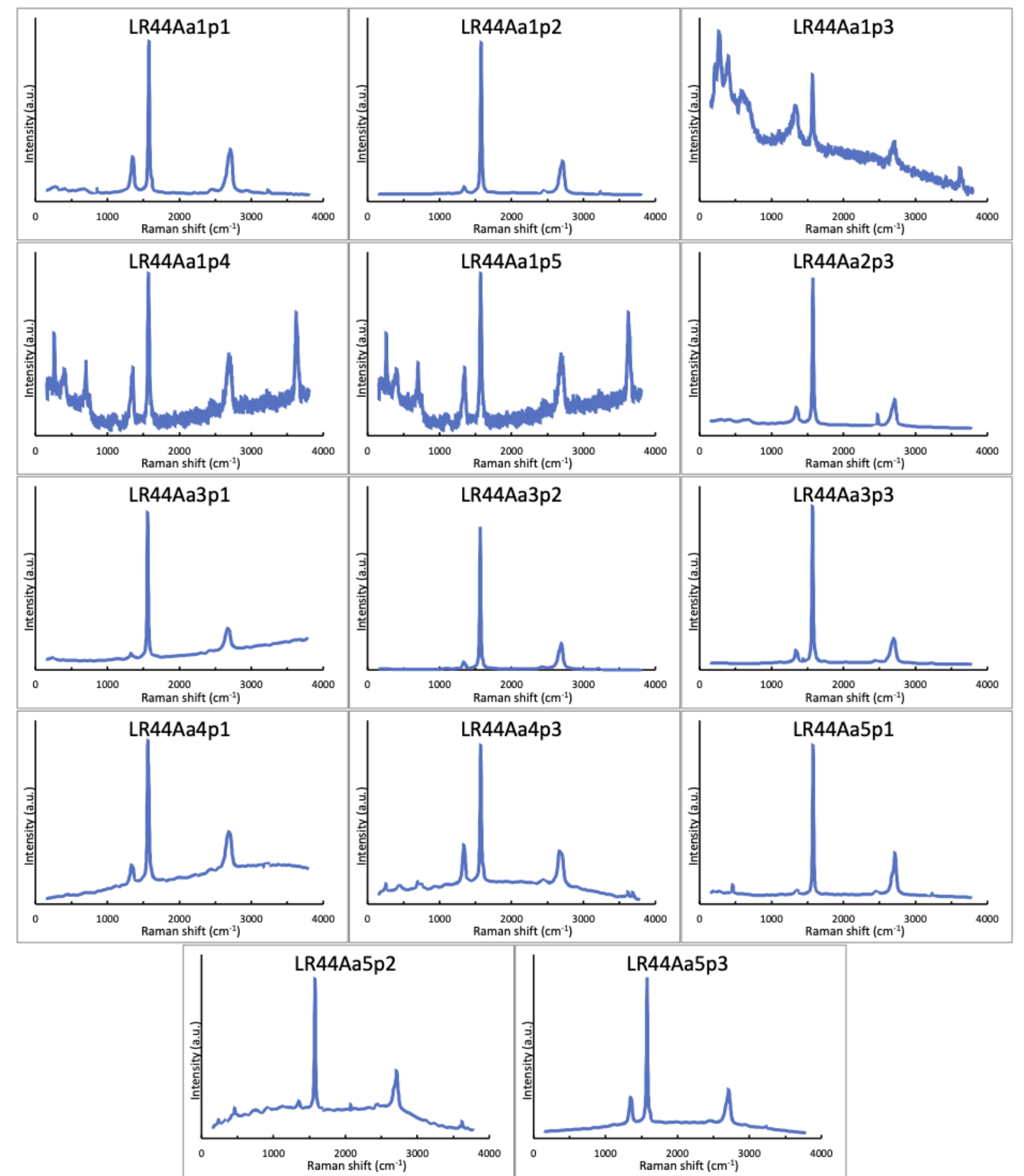

Figure 9. Raman spectra of analyses made on sample 44A presenting graphite pattern. Some samples show some interference due to the contamination of phengite. 


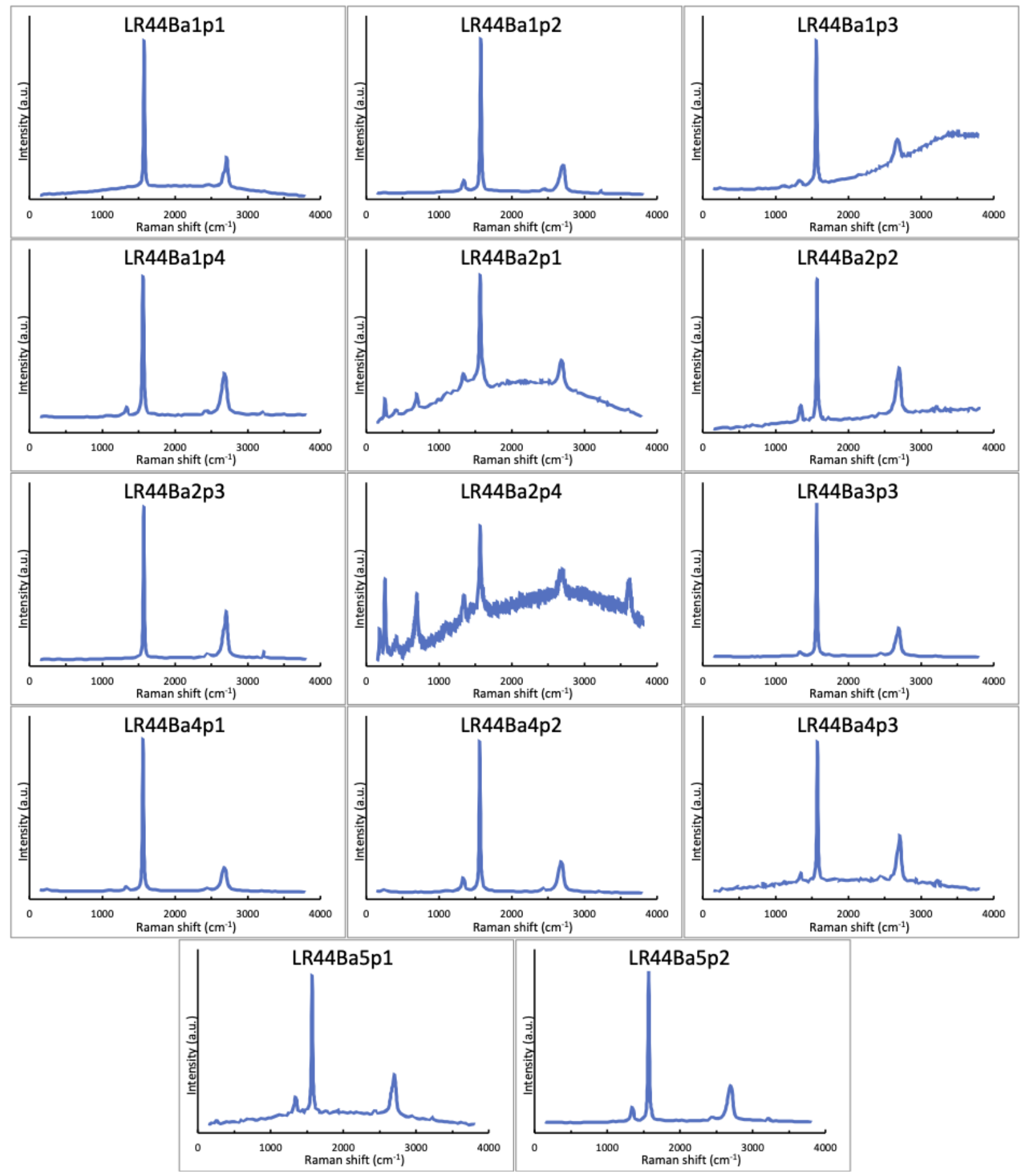

Figure 10. Raman spectra of analyses made on sample 44B presenting graphite pattern. Some samples show some interference due to the contamination of phengite.
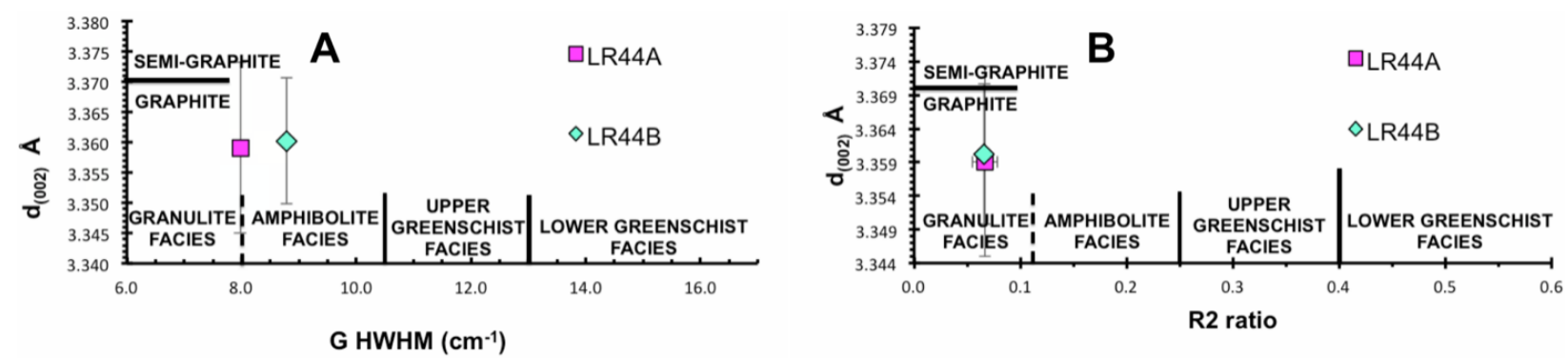

Figure 11. (A) d(002) versus half width at half maximum of the G-band (G HWHM) (Beyssac et al. 2002, Kwiecińska and Petersen 2004, Rantitsch et al. 2016). Sample LR44A is classified as upper amphibolite facies and LR44B as amphibolite facies; (B) d(002) versus area ratio (R2) (Kwiecińska and Petersen 2004, Rantitsch et al.2016). Both samples are classified as granulite facies. 
Table 3. Comparison between X-ray diffraction and Raman spectroscopy data from samples LR44A and LR44B of graphite schist. $\mathrm{d}(002)$ represents the interplanar spacing, GD is the graphitization degree, $\mathrm{T}$ is the metamorphic temperature in ${ }^{\circ} \mathrm{C}, \mathrm{G} H W \mathrm{HM}$ represents the width at half maximum of the G-band and $\mathrm{R} 2$ is the area ratio.

\begin{tabular}{|c|c|c|c|c|c|c|c|c|c|c|c|c|c|c|}
\hline \multirow{2}{*}{ Sample } & \multicolumn{7}{|c|}{ XRD } & \multicolumn{7}{|c|}{ Raman } \\
\hline & $\mathbf{n}$ & $d(002)$ & std & GD & std & $\mathbf{T}^{\circ} \mathbf{C}$ & std & $\mathbf{n}$ & G HWHM & std & $\mathbf{R 2}$ & std & $\mathbf{T}^{\circ} \mathbf{C}$ & std \\
\hline LR44A & 4 & 3.359 & 0.014 & 50.5 & 3.1 & 442 & 10 & 14 & 7.976 & 0.066 & 0.067 & 0.012 & 486 & 63 \\
\hline LR44B & 4 & 3.360 & 0.010 & 52.7 & 5.8 & 449 & 19 & 14 & 8.782 & 0.004 & 0.066 & 0.000 & 463 & 64 \\
\hline
\end{tabular}

XRD: X-ray diffraction.

as graphite (Kwiecińska and Petersen 2004) in both graphs presented in Figure 11.

An explanation for why the temperatures found by the XRD and Raman methods (Tab. 1), for both graphite schist samples, disagrees with the syn-collisional metamorphism (Chaves et al. 2015), and the classifications based on crystallinity (Rantitsch et al.2016), revealed in Figure 11, could be associated with a post-collisional stage. In this phase, the reactivation of old faults creates open space for fluid percolation (Carvalho et al. 2017, Miranda et al. 2019). It is possible to observe quartz veins apparently related with this event (Fig. 3D). According to Miranda et al. (2019), hydrothermal process can decrease the crystallite size, placing the samples into high-grade metamorphic fields, even when they were metamorphized in much lower temperatures, that is, around $460^{\circ} \mathrm{C}$. In their analyses, samples from hydrothermal recrystallized graphites had results similar to those presented here. They are classified as amphibolite facies in the correlation of Figure 8A and granulite facies in the correlation of Figure 11B, exactly as it happens to the samples analysed here.

The graphite schist from the Itapecerica region, which is adjacent to the present area of study, has biogenic origin (Miranda et al. 2019). As in Formiga area, todorokite (Mn-oxide mineral typical of deep-sea Mn nodules formed by microorganisms, as suggested by Lowenstam 1981) is also present. Given the geological and mineralogical similarities between the two areas, it is possible to assume that the graphite schist from Formiga also has biogenic origin. This carbonaceous material would have been deposited in an oceanic basin between the Campo Belo and Divinópolis complexes in the pre-collisional stage. During the Rhyacian-Orosirian orogeny, graphite schist would be metamorphized under granulite facies conditions and faults were formed. In post-collisional stage, the faults would have been reactivated turning into pathways to fluids which changed the graphite structure, decreased its crystallite size and changed the temperature signature to around $460^{\circ} \mathrm{C}$.

\section{CONCLUSION}

The graphite schist from Formiga presented temperature around $460^{\circ} \mathrm{C}$ by the XRD and Raman analyses. The hydrothermalism associated with a post-collisional event explains the decrease in the crystallite size of the graphite mineral and its low temperature, while temperature typical of granulite facies was expected. The occurrence of todorokite in quartz veins and the presence of graphite with $\delta^{13} \mathrm{C}$ between -21.23 and $-27.89 \%$ in the adjacent area (Miranda et al. 2019) suggest a biogenic origin for the carbonaceous material that resulted in the graphite schist from Formiga.

\section{ACKNOWLEDGEMENTS}

We are grateful to the Institute of Geosciences of UFMG that avail the CPMTC laboratories. The second author thanks Fundação de Amparo à Pesquisa do Estado de Minas Gerais (FAPEMIG) for research financial support through the project APQ00654-16.

\section{ARTICLE INFORMATION}

Manuscript ID: 20200083. Received on: 08/11/2020. Approved on: 09/21/2020.

L.R. and A.C. made the field work together. L.R. made the petrographic analyses, thermometric treatment of Raman and diffraction data, edited the Figures and Tables and wrote the manuscript. A.C. provided the X-ray diffraction data and improved and completed the manuscript. S.R. provided the Raman data.

Competing interests: The authors declare no competing interests.

\section{REFERENCES}

Alkmim F.F., Martins-Neto M.A. 2001. A Bacia Intracratônica do São Francisco: Arcabouço estrutural e cenários evolutivos. In: Martins-Neto M.A., Pinto C.P. (Eds.). Bacia do São Francisco. Belo Horizonte: SBG-MG, p. 9-30.

Alkmim F.F., Teixeira W. 2017. The Paleoproterozoic Mineiro Belt and the Quadrilátero Ferrífero. In: Heilbron M., Alkmim F., Cordani U.G. (Eds.). The São Francisco Craton and its margins, Eastern Brazil. Regional Geology Reviews. Switzerland: Springer, p. 71-94.
Almeida F.F.M. 1977. O Cráton do São Francisco. Revista Brasileira de Geociências, 7(4):349-364.

Ávila C.A., Teixeira W., Bongiolo E.M., Dussin I.A., Vieira T.A.T. 2014. Rhyacian evolution of subvolcanic and metasedimentary rocks of the southern segment of the Mineiro belt, São Francisco Craton, Brazil. Precambrian Research, 243:221-251. https://doi.org/10.1016/j. precamres.2013.12.028 
Baiju K.R., Satish-Kumar M., Kagi H., Nambiar C.G., Ravinsankar M. 2005. Mineralogical characterization of graphite deposits from Thodupuzha-Kanjirappally belt, Madurai granulite block, Southern India. Gondwana Research, 8(2):223-230. https://doi.org/10.1016/ S1342-937X(05)71120-5

Baltazar O.F., Zucchetti M. 2007. Lithofacies associations and structural evolution of the Archean Rio das Velhas greenstone belt, Quadrilátero Ferrífero, Brazil: A review of the setting of gold deposits. Ore Geology Reviews, 32:471-499. http://dx.doi.org/10.1016/j.oregeorev.2005.03.021

Beyssac O., Goffé B., Chopin C., Rouzaud J.N. 2002. Raman spectra of carbonaceous material in metasediments: A new geothermometer Journal of Metamorphic Geology, 20(9):859-871. https://doi. org/10.1046/j.1525-1314.2002.00408.x

Burns R.G., Burns V.M., Stockman H.W. 1983. A review of the todorokitebuserite problem: implications to the mineralogy of marine manganese nodules. American Mineralogist, 68(9-10):972-980.

Buseck P.R., Beyssac O. 2014. From organic matter to graphite: Graphitization. Elements, 10(6):421-426. https://doi.org/10.2113/ gselements.10.6.421

Campello M.S., Vaz B.B., Oliveira M.A.S., Ávila M.A.C. 2015. Folha Formiga (SF. 23-VB-III) Escala 1: 100.000. Projeto Fronteiras de Minas. Minas Gerais: CODEMIG/UFMG.

Carvalho B.B., Janasi V.A., Sawyer E.W. 2017. Evidence for Paleoproterozoic anatexis and crustal reworking of Archean crust in the São Francisco Craton, Brazil: A dating and isotopic study of the Kinawa migmatite. Precambrian Research, 291:98-118. https://doi.org/10.1016/j.precamres.2017.01.019

Chaves A.O., Campello M.S., Pedrosa-Soares A.C. 2015. Idade U-Th-PbT de monazitas do sillimanita-cordierita-granada-biotita gnaisse de Itapecerica (MG) e a atuação da orogenia Riaciano-Orosiriana no interior do Cráton São Francisco Meridional. Geociências, 34(3):324-334.

Dorr J.V.N. 1969. Physiographic, stratigraphic and structural development of the Quadrilatero Ferrifero, Minas Gerais, Brazil, U.S. Geological Survey Professional Paper, 641-A:110. https://doi.org/10.3133/pp641A

Farina F.A., Albert C., Lana C. 2015. The Neoarchean transition between medium and high-K granitoids: Clues from the Southern São Francisco Craton (Brazil). Precambrian Research, 266:375-394. https://doi. org/10.1016/j.precamres.2015.05.038

Galvez M.E., Beyssac O., Martinez I., Benzerara K., Chaduteau C., Malvosin B., Malavieille J. 2013. Graphite formation by carbonate reductionduring subduction. Nature Geoscience, 6:473-477. https://doi.org/10.1038/ ngeo 1827

Harlow G.E. 1998. The nature of Diamonds. Cambridge: Cambridge University Press.

Kwiecińska B., Petersen H. 2004. Graphite, semi-graphite, natural coke, and natural char classification-ICCP system. International Journal of Coal Geology, 57(2):99-116. https://doi.org/10.1016/j.coal.2003.09.003

Lowenstam H.A. 1981. Minerals formed by organisms. Science, 211 (4487):1126-1131. https://doi.org/10.1126/science.7008198

Lünsdorf N.K. 2015. Geothermometry by Raman Spectroscopy of Dispersed Organic Matter. PhD thesis, University of Göttingen, Göttingen, 113 p.

Lünsdorf N.K., Lünsdorf J.O. 2016. Evaluating Raman spectra of carbonaceous matter by automated, iterative curve-fitting. International Journal of Coal Geology, 160-161:51-62. https://doi.org/10.1016/j. coal.2016.04.008

Luque F.J., Pasteris J.D., Wopenka B., Rodas M., Barrenechea J.F. 1998. Natural fluid-deposited graphite: Mineralogical characteristics and mechanisms of formation. American Journal of Science, 298:471-498. https://doi.org/10.2475/ajs.298.6.471

Machado N., Schrank A., Noce C.M., Gauthier G. 1996. Ages of detrital zircon from Archean-Paleproterozoic sequences: Implications for greenstone belt setting and evolution of a Transamazonian foreland basin in Quadrilátero Ferrífero, southeast Brazil: Evidence from zircon ages by laser ablation ICP-MS. Earth Planetary Science Letters, 141(1-4):259-276. https://doi.org/10.1016/0012-821X(96)00054-4
Machado Filho L., Ribeiro M., Gonzales S.R., Schenini C.A., Santos Neto A., Palmeira R.C., Pires J.L., Teixeira W., Castro H.E.F. 1983. Geologia das folhas Rio de Janeiro (SF 23/24) escala 1:1.000.000, mapa e texto explicativo. Rio de Janeiro: RADAM Brasil, Ministério das Minas e Energia, 780 p.

Miranda D.A., Chaves A.O., Campello M.S., Ramos S.L.L.M. 2019. Origin and thermometry of graphites from Itapecerica supracrustal succession of the southern Sao Francisco Craton by C isotopes, X-ray diffraction, and Raman spectroscopy. International Geology Review, 61(15):1864-1875. https://doi.org/10.1080/00206814.2018.1564073

Moreira H., Lana C., Nalini Júnior H.A. 2016. The detrital zircon record of an Archaean convergent basin in the Southern São Francisco Craton, Brazil. Precambrian Research, 275:84-99. https://doi.org/10.1016/j. precamres.2015.12.015

Noce C.M., Machado N., Teixeira W. 1998. U-Pb Geochronology of gneisses and granitoids in the Quadrilatero Ferrifero (Southern São Francisco Craton): Age constraints for Archean and Paleoproterozoic magmatism and metamorphism. Revista Brasileira de Geociências, 28:95-102.

Noce C.M., Pedrosa-Soares A.C., Silva L.C.D., Alkmim F.F. 2007. O embasamento arqueano e paleoproterozóico do orógeno Araçuaí. Geonomos, 15(1):17-23. https://doi.org/10.18285/geonomos.v15i1.104

Rantitsch G., Lämmerer W., Fisslthaler E., Mitsche S., Kaltenböck H. 2016. On the discrimination of semi-graphite and graphite by Raman spectroscopy. International Journal of Coal Geology, 159:48-56. https://doi. org/10.1016/j.coal.2016.04.001

Simandl G.J., Paradis S., Akam C. 2015. Graphite deposit types, their origin, and economic significance. In: Simandl G.J., Neetz M. (Eds.), Symposium on Strategic and Critical Materials Proceedings. Victoria: British Columbia Geological Survey, p. 163-171.

Tagiri M. 1981. A measurement of the graphitizing degree by the X-ray powder diffractometer. Journal of Mineralogy, Petrology and Economic Geology, 76(11):345-352. https://doi.org/10.2465/ganko1941.76.345

Tagiri M., Oba T. 1986. Hydrothermal syntheses of graphite from bituminous coal at $0.5-5 \mathrm{kbar}$ water vapor pressure and $300-600^{\circ} \mathrm{C}$. Journal of Mineralogy, Petrology and Economic Geology, 81(7):260-271. https://doi. org/10.2465/ganko1941.81.260

Teixeira W., Ávila C.A., Dussin I.A., Corrêa Neto A.V., Bongiolo E.M., Santos J.O.S., Barbosa N. 2015. A juvenile accretion episode $(2.36-2.33 \mathrm{Ga})$ in the Mineiro belt and its role to the long-lived Minas accretionary orogeny: zircon U-Pb-Hf and geochemical evidences. Precambrian Research 256:148-169. https://doi.org/10.1016/j.precamres.2014.11.009

Teixeira W., Carneiro M.A., Noce C.M., Machado N., Sato K., Taylor P.N. 1996. $\mathrm{Pb}, \mathrm{Sr}$ and $\mathrm{Nd}$ isotope constraints on the Archean evolution of gneissic-granitoid complexes in the southern São Francisco Craton, Brazil. Precambrian Research, 78(1-3):151-164. https://doi. org/10.1016/0301-9268(95)00075-5

Teixeira W., Oliveira E.P., Peng P., Dantas E.L., Hollanda M.H.B.M. 2017. $\mathrm{U}-\mathrm{Pb}$ geochronology of the $2.0 \mathrm{Ga}$ Itapecerica graphite-rich supracrustal succession in the São Francisco Craton: Tectonic matches with the North China Craton and paleogeographic inferences. Precambrian Research, 293:91-111. https://doi.org/10.1016/j.precamres.2017.02.021

Wada I.H., Tomita T., Matsuura K., Tuchi K., Ito M., Morikiyo T. 1994. Graphitization of carbonaceous matter during metamorphism with reference to carbonate and pelitic rocks of contact and regional metamorphism, Japan. Contributions to Mineralogy and Petrology, 118(3):217-228. https://doi. org/10.1007/BF00306643

Whitney D.L., Evans B.W. 2010. Abbreviations for names of rock-forming minerals. American Mineralogist, 95(1):185-187. https://doi.org/10.2138/ am.2010.3371

Wintsch R.P., O’Connell A.F., Ransom B.L., Wiechmann, M.J. 1981. Evidence for the influence off $\mathrm{CH}_{4}$ on the crystallinity of disseminated carbon in greenschist facies rocks, Rhode Island, USA. Contributions to Mineralogy and Petrology, 77(3):207-213. https://doi.org/10.1007/ BF00373536

Young R.A. 1993. The rietveld method. International Union of Crystallography. New York: Oxford University Press, 298 p. 